\title{
Neoliberal Mining amid El Niño Induced Drought in the Philippines
}

\author{
William N. Holden ${ }^{1}$ \\ ${ }^{1}$ University of Calgary, 2500 University Drive NW, Calgary, Alberta, Canada \\ Correspondence: William N. Holden, University of Calgary, 2500 University Drive NW, Calgary T2N-1N4, \\ Alberta, Canada. E-mail: wnholden@ucalgary.ca
}

\author{
Received: September 29, 2012 Accepted: October 18, 2012 Online Published: December 17, 2012 \\ doi:10.5539/jgg.v5n1p58 \\ URL: http://dx.doi.org/10.5539/jgg.v5n1p58
}

\begin{abstract}
In recent years the government of the Philippines, acting in adherence to the principles of neoliberalism, has encouraged large-scale mining as a method of achieving economic development. The islands of the Philippines are, however, highly vulnerable to El Niño induced drought. Mining can interfere with groundwater resources, aggravate an El Niño induced drought, and deprive the rural poor of much needed water thus causing a disaster wherein a natural hazard impacts a vulnerable population. The possibility of mining adversely interacting with El Niño induced drought is aggravated by the deforestation of the Philippines and may well worsen due to anthropogenic climate change. Subjecting mining projects to environmental impact assessment and the mining industry's purported use of best practices in environmental management appear to be ineffective methods for ameliorating the risks posed by mining amid El Niño induced drought. These risks have generated substantial civil society opposition to mining in the Philippines.
\end{abstract}

Keywords: neoliberalism mining, natural hazards El Niño, Philippines, environmental impact assessment, ecautionary principle

\section{Introduction}

This article examines the problems emanating from the intersection of a mining based development paradigm with El Niño induced drought in the Philippines. In recent years, the government of the Philippines has attempted to accelerate the economic development of that nation by encouraging foreign direct investment by multinational mining companies. The Philippines is, however, a nation highly prone to natural hazards including El Niño induced drought. Mining related hydrologic disruptions occurring during an El Niño induced drought have the potential to disrupt resources relied upon by the poor and create a disaster, the situation where a natural hazard impacts upon a vulnerable population. This article exemplifies how disasters emerge from the nexus between natural hazards and policy decisions, as Bankoff (2003) wrote: 'hazards may be physical phenomena but disasters occur as a result of a community's political structure, economic system, and social order that expose its people to the dangers inherent in extreme seismic or climatic disturbances.'

The major methodological approach used in this article is mapping and maps have been constructed depicting the overlap of mining projects with vulnerability to El Niño induced drought. The information detailing the location of mines was published by the Mines and Geosciences Bureau, of the Philippine government's Department of Environment and Natural Resources (DENR). This data was entered into a geographical information system database and overlaid upon map layers displaying vulnerability to El Niño induced drought obtained from the website of the Manila Observatory, an institution that has collected data on natural hazards in the Philippines since 1865 (Bankoff, 2003).

\section{Theoretical Framework: 'Disaster' Defined}

A 'disaster' is defined as the situation when 'a significant number of vulnerable people experience a hazard and suffer severe damage and/or disruption of their livelihood system in such a way that recovery is unlikely without external aid' (Wisner et al., 2004). The essence of a disaster is 'the impact of hazards on vulnerable people' (Wisner et al., 2004). The crucial aspect of understanding a disaster is the involvement of vulnerable people. A high magnitude earthquake occurring in Antarctica would not constitute a disaster since no vulnerable population would be effected; similarly, the landing of a typhoon upon an uninhabited island would also fail to constitute a disaster as no vulnerable population would be effected. 
'Vulnerability' is defined by Wisner et al. (2004) as 'the characteristics of a person or group and their situation that influence their capacity to anticipate, cope with, resist and recover from the impact of a natural hazard.' To Bankoff (2003), 'Vulnerable populations are those at risk not simply because they are exposed to hazard, but as a result of marginality that makes of their life a "permanent emergency"'. The Department of Environment and Natural Resources Climate Change Office (2010) described vulnerability as "the "capacity to be wounded." Perhaps the best indicator, or determinant, of vulnerability is poverty; the poor have little, if any, capacity to cope with a hazard and, consequently, are highly vulnerable (Bankoff \& Hilhorst, 2009). If the poor are concentrated in a location where they are impacted by a natural hazard (even one constituting what would only be an inconvenience to more affluent members of society) they will be plunged from subsistence into destitution thus creating a disaster.

\section{Neoliberal Mining in the Philippines}

\subsection{Neoliberalism: Unlimited Growth through Unfettered Markets}

'Neoliberalism' is a theory proposing the advancement of human welfare through the liberation of entrepreneurial freedoms within 'an institutional framework characterized by strong property rights, free markets, and free trade' (Harvey, 2005). The prefix 'neo' is added to the word 'liberalism' because neoliberalism can be traced back to the teachings of the classical liberals, such as Adman Smith, because these philosophers considered 'any restraint on free competition would interfere with the natural efficiency of market mechanisms, inevitably leading to social stagnation, political corruption, and the creation of unresponsive state bureaucracies' (Tyner, 2009). The 'central features of neoliberalism include the primacy of economic growth, the importance of free trade to stimulate growth, the promotion of an unrestricted free market, individual choice, privatization of business, the reduction of governmental regulation, and the advocacy of an evolutionary model of social development anchored in the Western experience and applicable to the entire world' (Tyner, 2009). Perhaps the most influential institution in the diffusion of neoliberalism has been the World Bank (Broad \& Cavanagh, 2009). Created in 1944, the World Bank was designed to provide financial and technical assistance to developing countries but, by the 1960s, it began to influence the governments of developing countries in replacing nationalist economic policies with transnational policies promoting exports and, by the late 1970s, it began attaching conditions on loans made to developing countries that typically involved changes to tariffs, tax rates, interest rates and public spending by the recipient nations. Eventually, after having received a steady diet of free market advice from the World Bank, almost all of the countries in the developing world restructured their economies in accordance with the precepts of neoliberalism (Bello et al., 2009). One of the most important components of neoliberalism in the developing world is the promotion of foreign direct investment, which is perceived to be a conduit for much needed capital into underdeveloped countries (Peet \& Hartwick, 2009). Barriers impeding the entry of foreign firms should be abolished thus allowing foreign and domestic companies to compete on an equal footing.

\subsection{Neoliberal Mining in the Developing World}

Just as the World Bank has encouraged foreign direct investment as a development strategy, it has also specifically encouraged foreign direct investment in mining (Bebbington et al., 2008). This strategy began to become apparent when two highly influential World Bank publications emerged during the early 1990s (Strongman, 1994; World Bank, 1992). These reports argued against public ownership of mining companies in developing countries, placing an emphasis on mining projects aimed primarily at production for export instead of for the domestic economy, and making it clear that the World Bank's emphasis was on opening up the mining sector in developing countries to direct investment from multinational mining companies. These reports had a substantial impact on the crafting of mining codes (Moody, 2007) and more than 90 states have adopted new mining laws, or revised existing ones, in an effort to increase foreign investment in mining (Bridge, 2007). As Bebbington et al. (2008) wrote, 'the increase of investment in developing countries has been palpable'.

\subsection{Neoliberal Mining in the Philippines}

The Philippines, an archipelago of approximately 7,100 islands in Southeast Asia (Figure 1) has enthusiastically adhered to the principles of neoliberalism. The acceptance of neoliberalism is widely attributed to President Fidel Ramos (1992-1998) who implemented a rigorous program of reforms entitled 'Philippines 2000' aiming to make the Philippines a developed country by the year 2000 and one of best examples of neoliberalism in the archipelago has been the government's promotion of large-scale mining by multinational corporations (Holden \& Jacobson, 2012). 


\section{The Philippines}

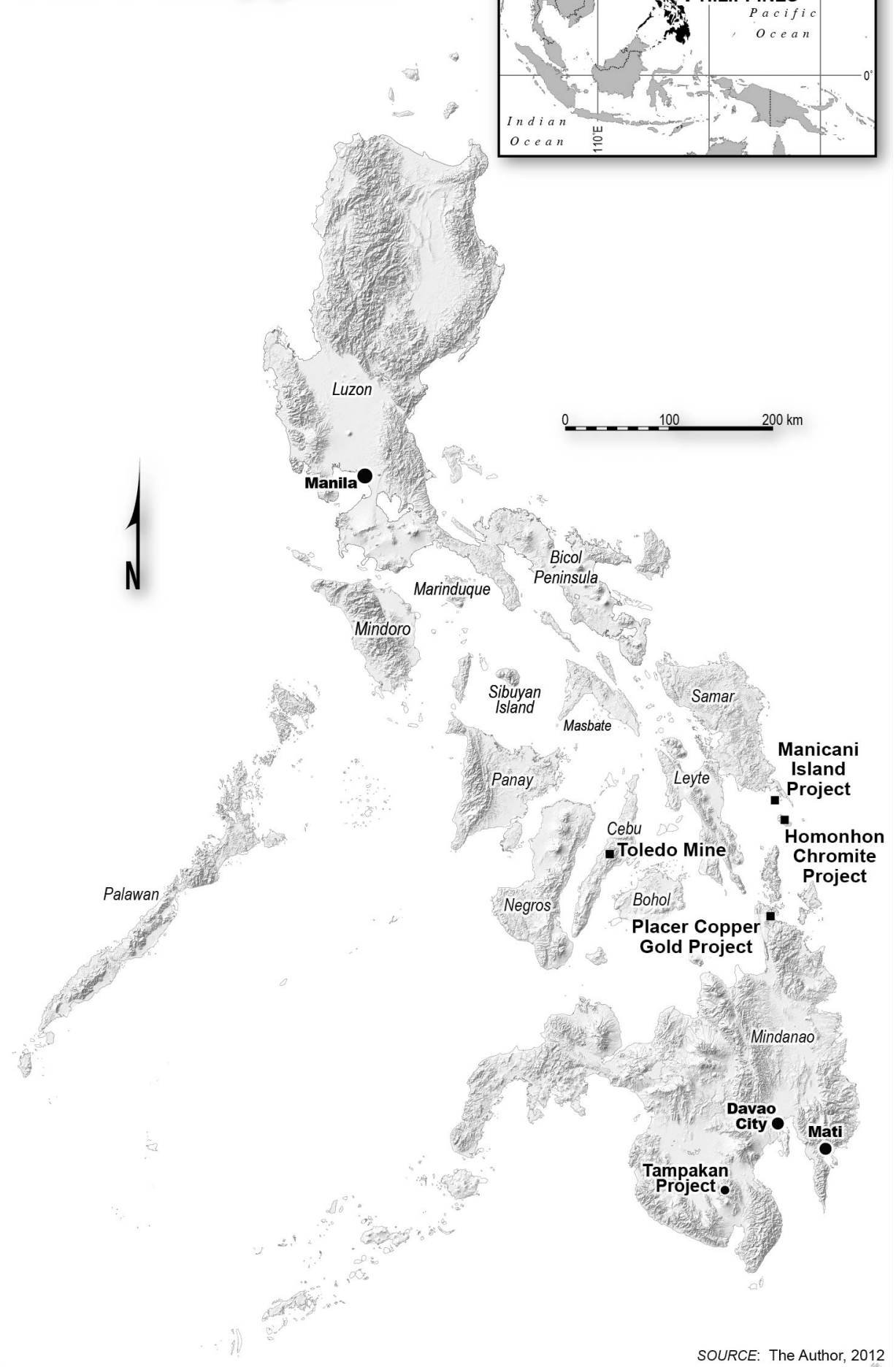

Figure 1. The Philippines, an archipelago of approximately 7,100 islands in Southeast Asia

The Philippines are amongst the most highly mineralized countries in the world and it is estimated that 30 percent of the archipelago's land area has the potential to host commercially viable ore deposits (Department of Environment and Natural Resources Climate Change Office, 2010). In 1995, in an effort to stimulate economic development, President Ramos signed into law the Mining Act of 1995 (Republic Act 7942), which contained a number of incentives to encourage mining such as: tax holidays; duty-free capital equipment imports; value-added tax exemptions; tax deductions for operations posting losses; accelerated depreciation; guarantees of 
the right of profit repatriation; and freedom from expropriation (Holden \& Jacobson, 2012). By the beginning of the twenty-first century the government of the Philippines had placed expectations upon mining as something capable of generating jobs, eradicating poverty, and providing services to communities in rural areas. As Romulo Neri (2005), Director General of the National Economic Development Authority, stated: 'The mining industry's growth is truly crucial in inducing greater economic growth, attracting more investments, creating more jobs, and relieving poverty particularly in the rural areas'. These efforts to attract foreign mining companies have been quite successful and from 2004 to 2010 investment in mining increased, on average, by 30 percent each year (Holden \& Jacobson, 2012). 'The Philippines has taken great strides', stated an unnamed exploration company president, 'to attract investors through policy and promotion' (Fraser Institute, 2008).

\section{Methods}

\subsection{The Disaster Vulnerability of the Philippines}

An extensive body of literature exists documenting the vulnerability of the Philippines to natural hazards (Bankoff, 2003; Bankoff \& Hilhorst, 2009; Holden \& Jacobson, 2012). 'The Philippines,' wrote Bankoff (2003) 'is both geophysically and meteorologically one of the world's natural hazard "hot spots". To Bankoff and Hilhorst (2009), the archipelago is one 'of the world's most hazardous landmasses.' Not only are the islands susceptible to natural hazards but they are also inhabited by a vulnerable population where approximately 70 percent of the poor depend directly upon agriculture related economic activities for their livelihood (Holden, 2011). The islands of the Philippines contain a substantial degree of rural poverty and it is estimated that 44 percent of all farmers live in poverty (Department of Environment and Natural Resources Climate Change Office, 2010). These people rely on access to natural resources for their existence; what Nadeau (1992) described as 'the ecological dependence of peasant livelihood.' 'Environmental deterioration is crucial to a resource-dependent society because it diminishes their ability to provide for their basic needs' (Roque \& Garcia, 1993). Small farmers are vulnerable to environmental degradation and 'as environmental quality decreases, they become poorer and their options for a better life diminish' (Roque \& Garcia, 1993). A good description of the importance of natural resources to the poor is that given by Broad (1994): 'To live, poor people eat and sell the fish they catch or the crops they grow- and typically those who manage to subsist in this way do so with very little margin. Natural resource degradation often becomes an immediate and life- and livelihood- threatening crisis- a question of survival.'

\subsection{The Vulnerability of the Philippines to El Niño Induced Drought}

The El Niño phenomenon occurs when abnormal global weather conditions appear over large portions of the world for several months. This phenomenon originates in the southeastern Pacific Ocean where the Peru Current brings cold water into the tropics from Antarctica. This cold current is associated with high air pressure which, by suppressing precipitation, creates the desert-like climatic conditions found along the west coast of South America. When this current interacts with the prevailing trade winds blowing from east to west in equatorial latitudes there will be low air pressure prevailing in the western Pacific Ocean and, since this low air pressure does not suppress precipitation, places in the western Pacific often experience high levels of precipitation. This pattern of high air pressure, with low levels of precipitation, in the eastern Pacific and low air pressure, with high levels of precipitation, in the western Pacific is one of the great climatic constants of the tropical Pacific.

Often, during the month of December, a current of warm water will move south from the tropics and suppress the Peru Current. Since this often happens just before Christmas it is referred to by South American fisherfolk as El Niño (Spanish for the little boy) in honor of the baby Jesus (Katz, 2002; Philander, 2004). In most years this departure from the normal lasts only around 30 days until the cold Peru Current can reestablish itself. However, once every three to seven years, this phenomenon becomes very strong and lasts for several months and, in this case, an El Niño event is said to be underway.

During an El Niño event conditions in the tropical Pacific reverse themselves and what is normal in the eastern pacific becomes prevalent in the western Pacific and what is normal in the western Pacific becomes prevalent in the eastern Pacific hence the use of the term 'El Niño Southern Oscillation' (ENSO) to describe an El Niño event (Katz, 2002). During an El Niño, atmospheric pressures will shift and the westward blowing trade winds will slacken and even reverse themselves. Sea levels in the western Pacific will begin to fall and warm water will slip back towards South America disrupting the cold Peru Current (Bankoff, 2003). As this normally cold current becomes altered the eastern Pacific Ocean warms and air pressure becomes reduced; with lower air pressure in the eastern Pacific extremely heavy rains will develop in normally arid Peru (Van Aalst, 2006; Warner \& Ore, 2006). As extremely heavy rains develop in Peru, colder drier air that normally descends over the eastern Pacific 
shifts further east and descends over Southeast Asia, lowering rainfall levels and triggering drought (Dawe et al., 2008; Rodolfo \& Siringan, 2006).

In the Philippines there has been severe drought conditions associated with El Niño events during 1982-1983, 1990-1992, 1997-1998, 2005-2006 and 2009-2010 (Holden \& Jacobson, 2012). The 2010 El Niño induced drought was a serious event, especially on Mindanao (Figure 2), leading to power failures (as hydroelectric reservoirs were unable to maintain large enough supplies of water to generate electricity) and hundreds of millions of dollars worth of agricultural production was lost (Holden \& Jacobson, 2012).

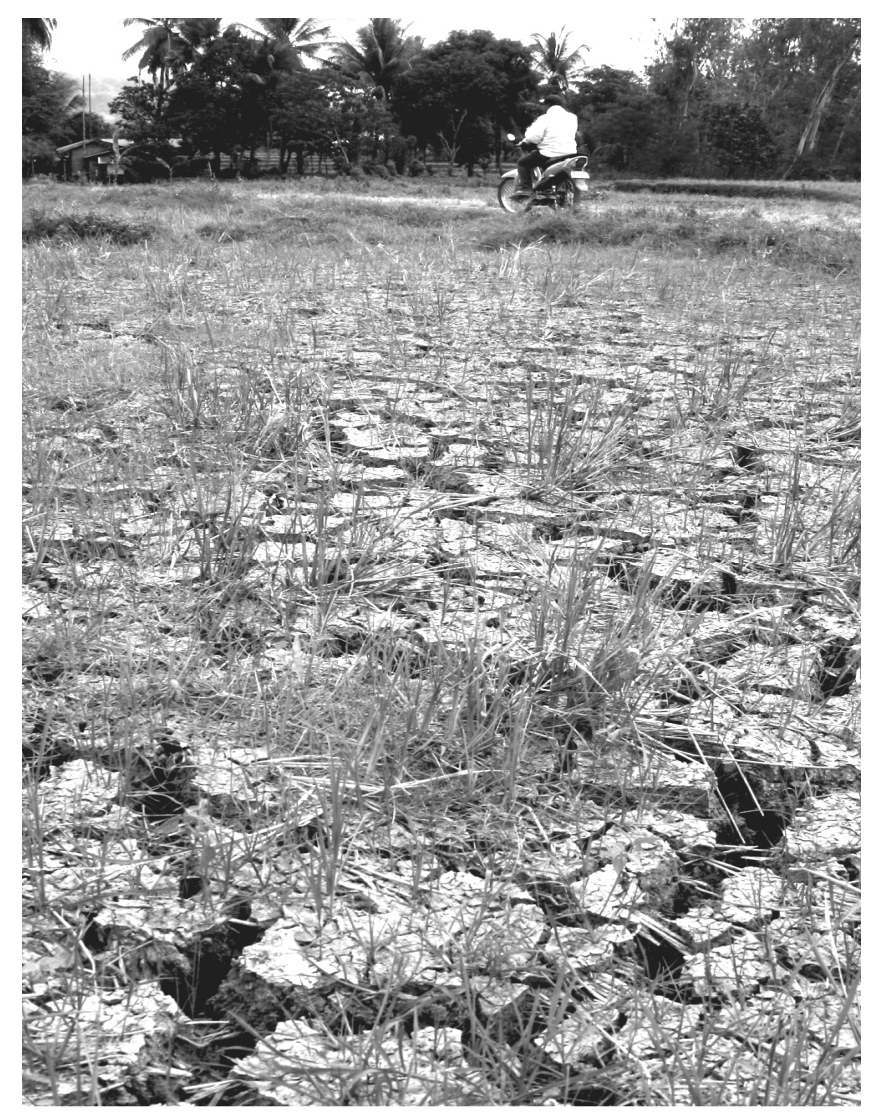

Figure 2. Dried cropland on Mindanao, 2010 El Niño

Photo Credit: Keith Bacongco, used with Permission.

Nevertheless, of all the El Niño induced droughts the 1997-1998 one stands out as the most calamitous affecting five million people, particularly on Mindanao (Bankoff, 2003). During this drought there were reports of people dying from eating kayos, a type of root crop containing a highly toxic poisonous alkaloid, which must be soaked in running water prior to being eaten (Bankoff, 2003). Water was unavailable for soaking the kayos, and, in the absence of any other type of food, these people ate the kayos out of desperation and with tragic results After this drought, the government pursued an extensive policy of using groundwater through the installation of shallow tube wells and, by the end of 1998, it had financed the construction of over 12,000 of these wells (Rodolfo \& Siringan, 2006). However, the extraction of groundwater can never be more than a temporary measure for drought alleviation since its slow replenishment rate means resources are rapidly depleted and an extensive use of shallow tube wells can lead to an exhaustion of groundwater (Bankoff, 2003).

What imparts into these El Niño induced droughts a serious potential for harm is the heavy reliance upon rice as a food staple by poor Filipinos. In the Philippines rice accounts for a substantial portion of total expenditure among the poorest 20 percent of the population and this proportion of the population consumes substantially more rice than it produces (Dawe et al., 2008). Not only is rice the principal staple of the poor it is also an extremely water-intensive crop and the hybrid varieties developed during the green revolution use proportionately more water than traditional varieties (Dawe et al., 2008; Rodolfo \& Siringan, 2006). Rice is also 
highly sensitive to water stress and its yields are vulnerable to loss from insects and weeds during periods of dry weather (Bankoff, 2003).

Corn, another staple commodity in the archipelago, is also vulnerable to drought as it requires at least 90 millimeters of rain every month during its first 90 days; if inadequate levels of moisture are available for corn the plants become stunted and the ears will not fill out (Bankoff, 2003). This is a serious concern since corn farmers are among the most impoverished farmers in the Philippines so any diminution of their ability to raise their crops has grave impacts upon their livelihoods (Seasonal Climate Forecast Project Updates, 2006).

\title{
4.3 Mining's Impact on Hydrologic Resources
}

Mining is an activity containing a substantial potential for environmental harm (Bebbington et al., 2008). Two of mining's most notorious environmental effects are its use of cyanide, a highly toxic substance, as a chemical processing agent in gold mining and the phenomena known as acid mine drainage, where acid is emitted from mining operations (Bravante \& Holden, 2009). However, even if a mine spills no chemicals, nor generates any acid mine drainage, mining may have serious impacts upon water resources in terms of its impacts upon water availability. Mines are heavy water users with a large-scale gold mine being expected to use between fifteen to thirty billion liters of water per year (Bleiwas, 2012); as Shomaker (2005) wrote:

\begin{abstract}
Mining enterprises always require water. The uses vary widely: dust suppression, milling, and processing, conveyance of tailings from mills, recovery of metals by leaching, dewatering of underground workings, and reclamation of mined lands. Apart from simple dewatering, most of these uses can lead to relatively high depletion- most of the water is lost to evaporation, rather than to the surface water or ground water system.
\end{abstract}

One of the most serious opportunities for mining to impact water availability is through the process of mine dewatering. Often ore bodies are below the water table (Figure 3a). When the mine workings (pits in the case of open pit mining or shafts and tunnels in the case of underground mining) go below the water table they will flood unless water is continually pumped out of the mine (Figure $3 b$ ) and, should mine pit dewatering ever stop, a pit-lake will form within the pit where the ground water reestablishes itself (Figure 3c). To prevent pit lakes forming, mines that go below the water table engage in pit dewatering continually pumping groundwater out of the pit. While this may prevent the pit from flooding it 'often involves the dewatering of large areas, which can create long-term ground water deficits and affect surface water flows as well as seeps and springs' (Kuipers, 2005).

Should there be one mine in an area, groundwater withdrawal at this mine will have the potential to generate a cone of depression in the aquifer near that mine and if successively more water is removed from this mine its cone may join those created by neighboring mines and this will lower the regional water table. This may lead to a reduction in flows in springs and streams some distance from the mine. Consequently, an important concern in mining is 'the potential cumulative effects of dewatering wells and groundwater wells for processing associated with several neighboring mines' (National Research Council, 1999). In such case the 'cones of depression in the deep aquifer resulting from groundwater withdrawal may coalesce and affect regional spring and stream flows that are dependent on the aquifer' (National Research Council, 1999). 

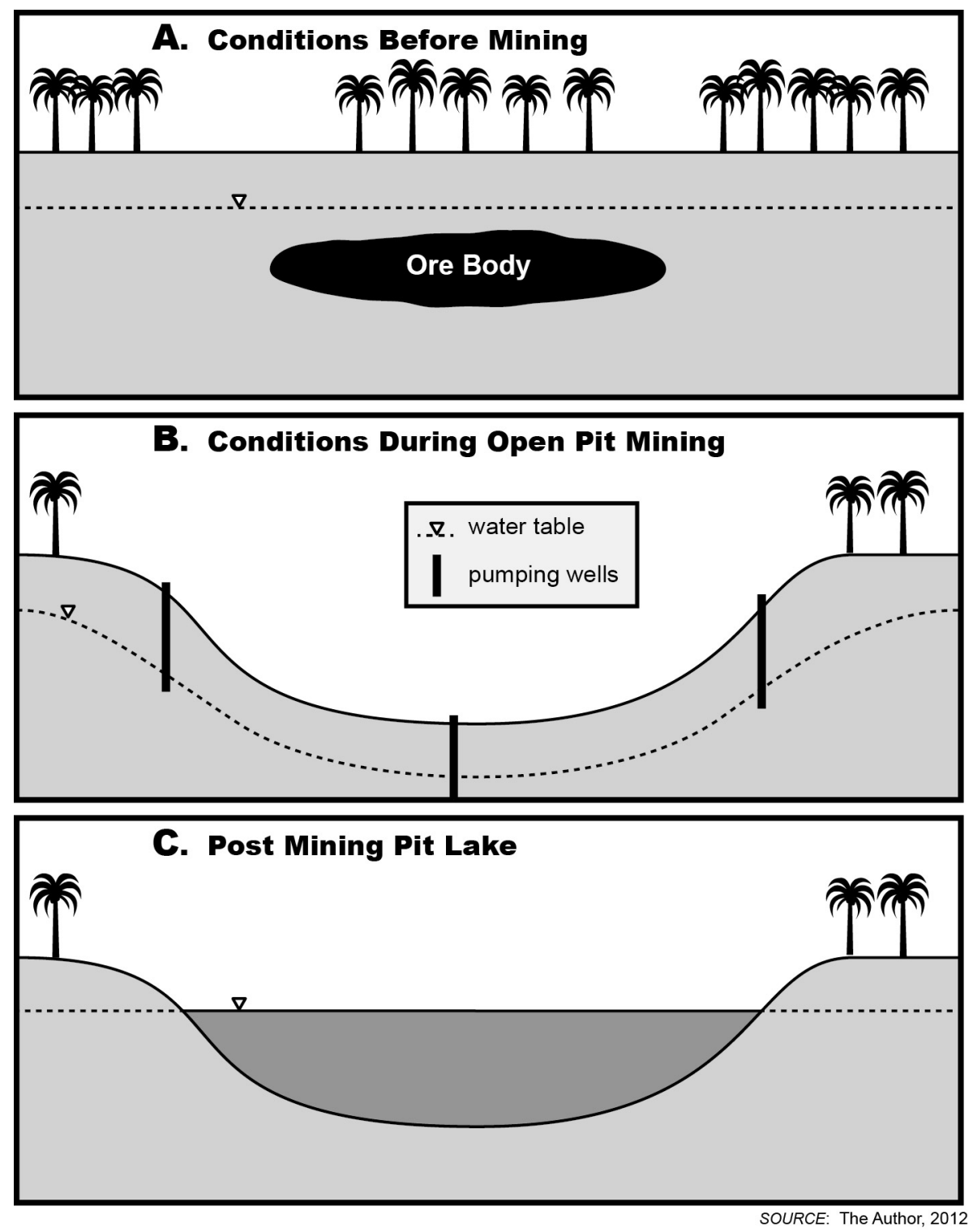

Figure 3. The Process of Mine Pit-Dewatering

\subsection{Mining and El Niño Interactions in the Philippines}

There have been documented instances where mining operations have interacted with drought in the Philippines. A severe drought on the island of Cebu during 1970 curtailed production at Atlas Consolidated Mining's Toledo Mine (United States Bureau of Mines, 1970). Emanuel Isip, the Technical Director of the Protected Areas and Wildlife Bureau (PAWB) of the DENR for southeastern Mindanao, related his experience as the Environmental Management Bureau (EMB) Director for northeastern Mindanao when mine pit dewatering at the Placer Copper Gold Project, operated by Manila Mining Corporation, caused creeks to dry up (Isip, 2005). Narcissa Baddilla, the Coordinator of the Save Manicani Movement, stated that during an El Niño there will be a noticeable decrease in groundwater on Manicani Island, particularly in the immediate vicinity of the Manicani Island Project, a nickel mine, and that groundwater can only be extracted for one hour each day (Baddilla, 2012). On Homonhon Island, where there is chromite mining, Villardo Abueme, the President of the Homonhon Environment Resources Organization, has observed mining's effect on groundwater availability during an El Niño and indicated that whenever there are three weeks of sunny weather there will be a reduction in groundwater; this was never the case before mining (Abueme, 2012). 


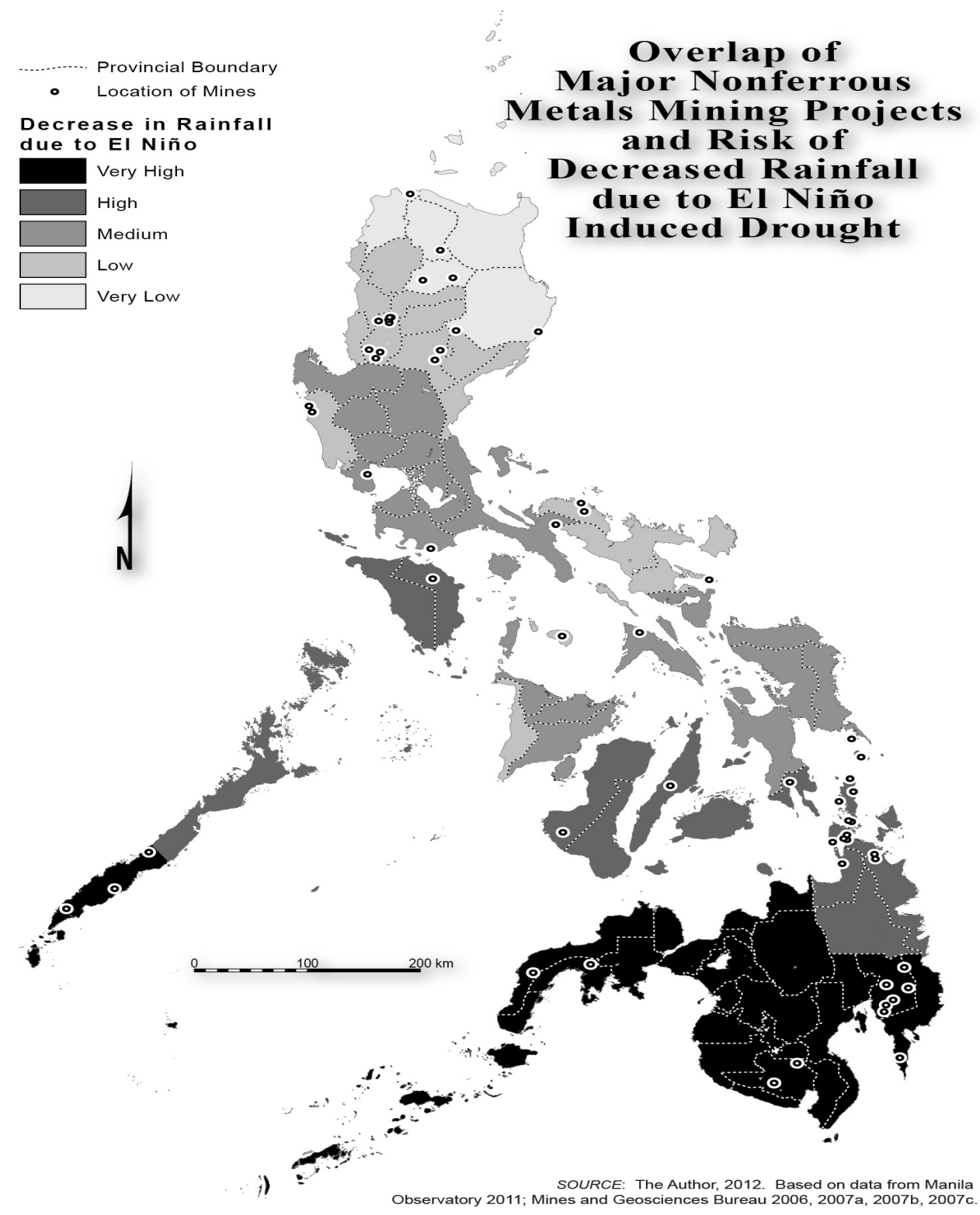

Figure 4. Overlap of mines and risk of El Niño induced drought

There are areas in the Philippines, particularly on the island of Mindanao, where mining projects overlap with the risk of El Niño induced drought and Figure 4 depicts this overlap showing that 24 percent of all mining projects are located in areas (Negros, Cebu, southern Leyte, and the northeastern portion of Mindanao) that are at high risk of drought during an El Niño event while 28 percent of all mining projects are located in areas (southern Palawan, and the remainder of Mindanao) that are at very high risk of being impacted by El Niño induced drought. In total, 52 percent of all mining projects are located in areas where there is either a high or very high risk of El Niño induced drought. 


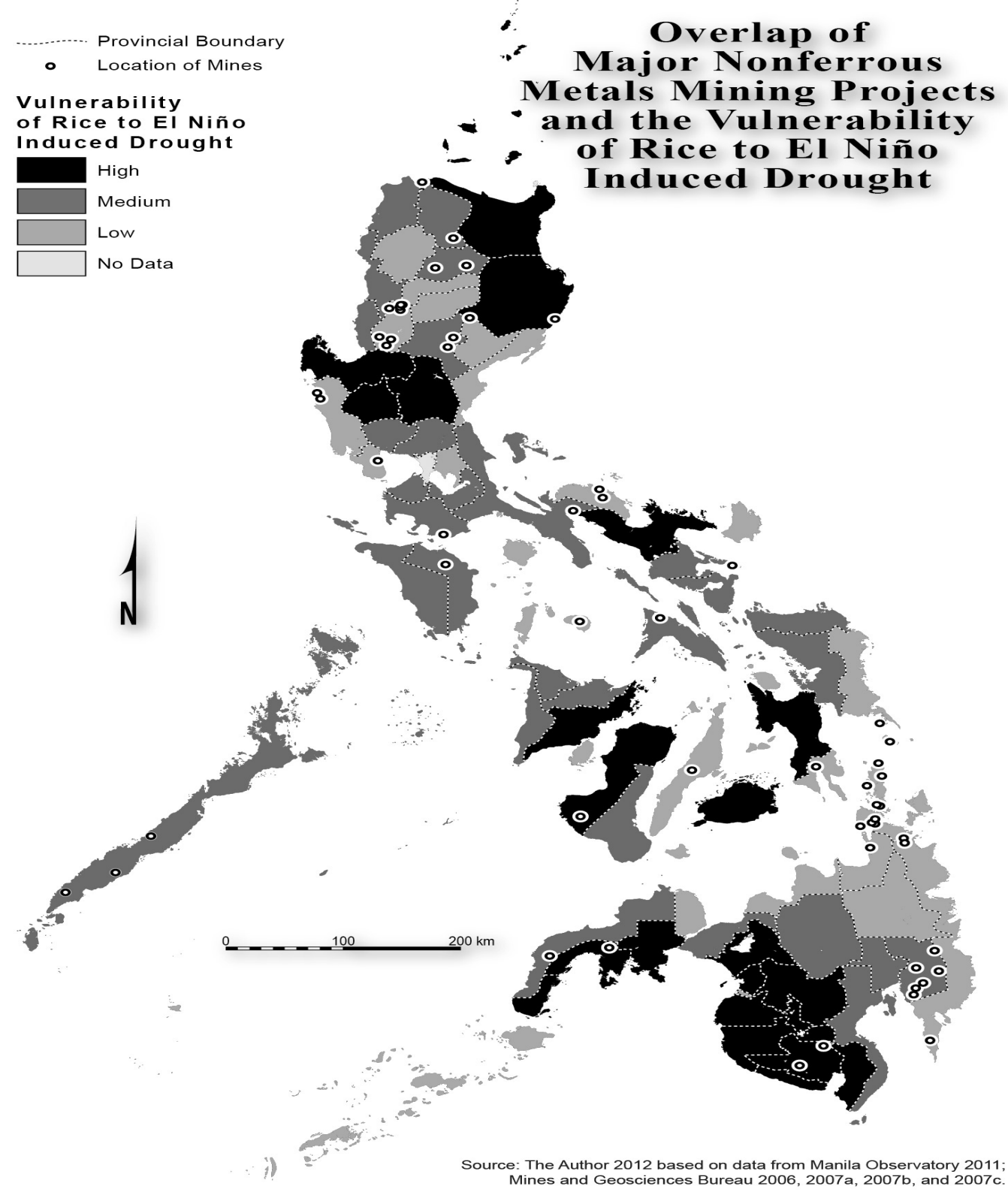

Figure 5. Overlap of Mines with the vulnerability of Rice to El Niño induced drought

In Figure 5 the overlap of mining projects with the vulnerability of rice to El Niño induced drought is portrayed and 48 percent of all mining projects are located in areas where rice experiences at least a medium vulnerability to El Niño induced drought. Similarly, Figure 6 shows the overlap of mining projects with the vulnerability of corn to El Niño induced drought and 29 percent of all mining projects are located in areas where corn experiences at least a medium vulnerability to El Niño induced drought. 


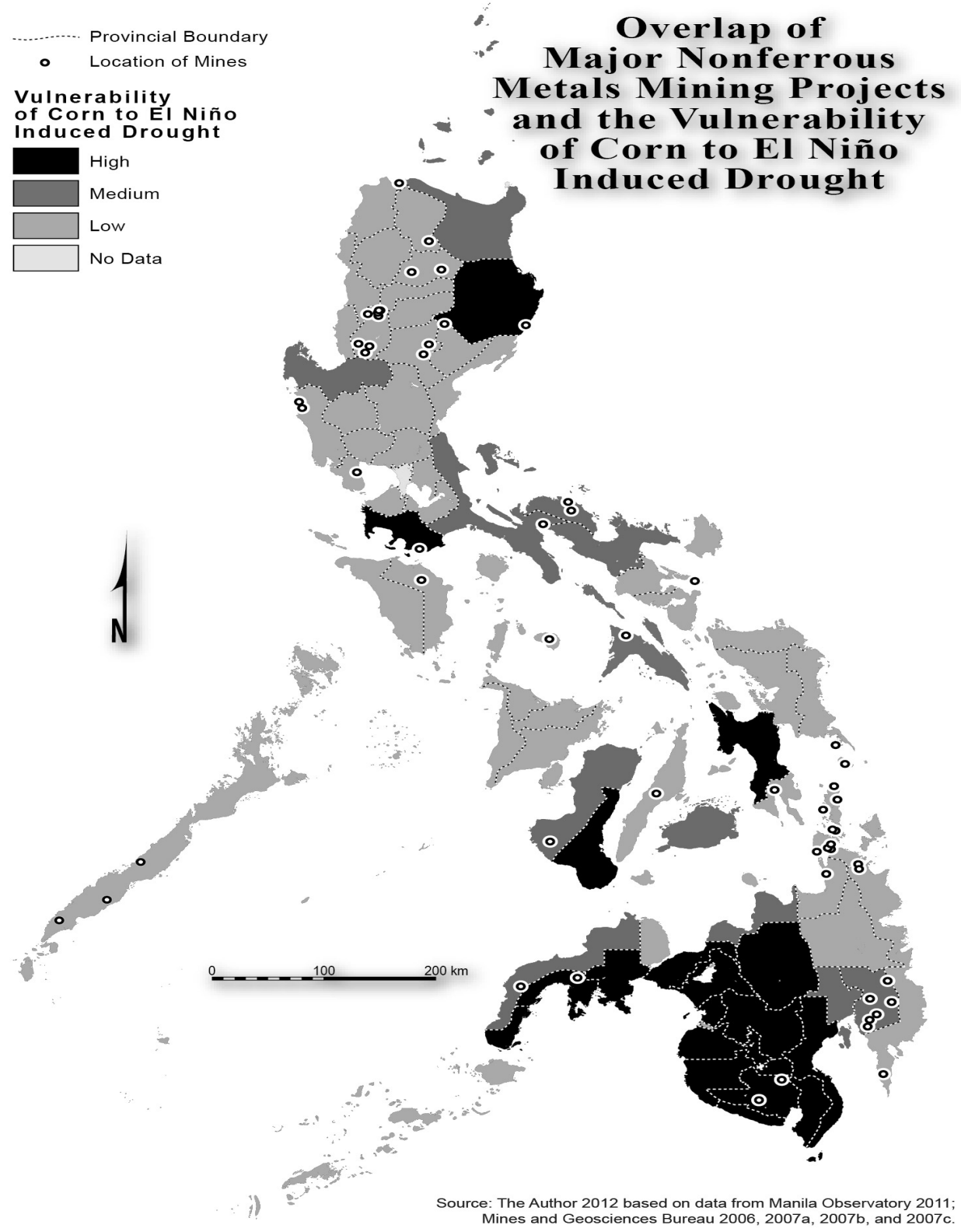

Figure 6. Overlap of Mines with the vulnerability of Corn to El Niño induced drought

Given the overlap of mining projects with the risk of El Niño induced drought, and given the overlap of mining projects with the vulnerability of rice and corn to El Niño induced drought, an El Niño induced drought leading to a reliance upon (and possible exhaustion of) groundwater resources will make many areas across the archipelago vulnerable to mining related hydrological disruptions. Indeed, by February 2010, the Alyansa Tigil Mina (Alliance to Stop Mining, an advocacy group on environmental issues, or ATM), concerned about mining's impact on groundwater resources, called for the government to issue a moratorium on large-scale mining during El Niño events in order to mitigate the effects of drought (Alyansa Tigil Mina, 2010). According to the ATM, provinces encountering drought during an El Niño will have better chances of coping with water stress if moratoriums on mining are imposed (Alyansa Tigil Mina, 2010).

The most prominent example of a mine with potential to adversely interfere with water resources is the Tampakan Project, in the Province of South Cotabato. The Tampakan mine is being developed by Sagittarius Mines Incorporated, which is owned by Switzerland's Xstrata (62.5 percent), Australia's Indophil Resources (34.2 percent), and the Alsons Corporation of the Philippines (3.3 percent) (Xstrata, 2008). This 'proposed project has the potential to be largest mine in the Philippines and one of the largest copper mines in the world' 
(AECOM Philippines Inc., 2011). This mine will be developed using open pit methods and the pit is projected to take up an area of approximately 7,500 square meters with a depth of approximately 800 meters (AECOM Philippines Inc., 2011). In the vicinity of this mine, the groundwater levels range from as low as 50 meters below the surface up to the surface itself (AECOM Philippines Inc., 2011). This mine is expected to use up to 78,450 liters every day during operation and the project proponent admits that there will be 'a decline in the groundwater levels in areas nearby the mine due to the open pit' (AECOM Philippines Inc., 2011). The province of South Cotabato is, however, an area that experiences a very high risk of El Niño induced drought and both rice and corn are highly vulnerable to El Niño induced drought in South Cotabato. When these facts are coupled with the fact that over 90 percent of all local domestic water supply in the vicinity of the mine come from groundwater (AECOM Philippines Inc., 2011) one sees the potential for a mining related disruption of groundwater. Should this mine interfere with the groundwater of South Cotabato it will exacerbate an already vulnerable water situation.

\subsection{Mining, El Niño Induced Drought, and Deforestation in the Philippines}

Something aggravating these concerns about interactions between mining and El Niño induced drought is the deforestation of the Philippines. From 1575 until 1997, the Philippines experienced an annual deforestation rate of 0.39 percent (IBON, 2006). Deforestation accelerated substantially during the twentieth century; in 1900, old-growth rain forest covered approximately 70 percent of the national land area but by 1992, the percentage of land area covered by old-growth forest had been reduced to only 8 percent in scattered and fragmented patches distributed through the archipelago (Heaney \& Regalado, 1998). Deforestation contributes substantially to drought because water that runs-off quickly does not enter the groundwater (Heaney \& Regalado, 1998).

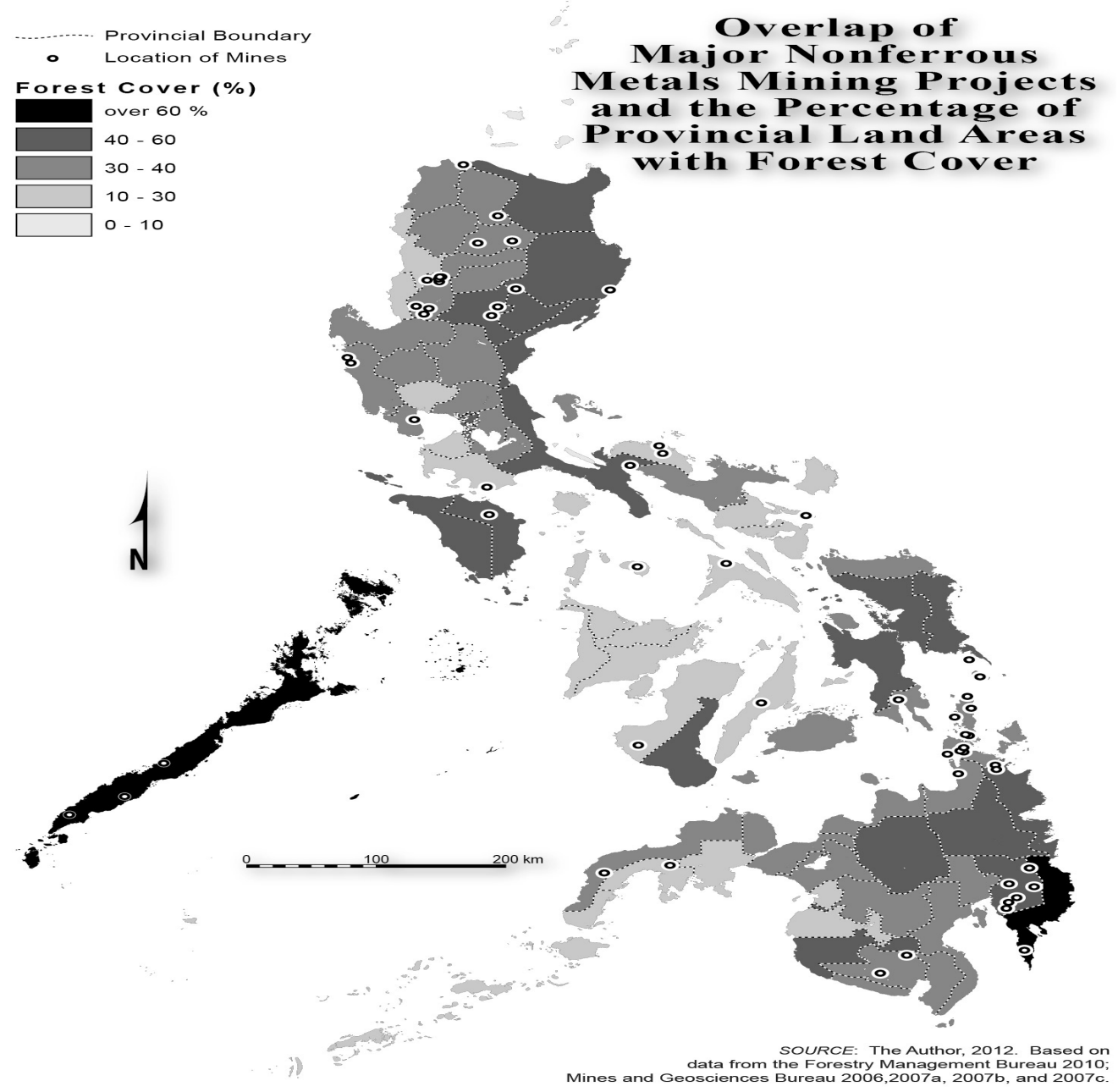

Figure 7. Overlap of mines with deforestation 


\subsection{El Niño Induced Drought, Climate Change, and Mining in the Philippines}

Concerns about the effects of mining amid El Niño induced drought grow when one takes into account that the frequency and severity of El Niño events may also be increasing as a result of anthropogenic climate change (emphasis is added to the word 'may' because there is uncertainty about the impact of climate change upon the ENSO). There is no doubt as to the validity of scientific studies indicating that the world's climate is warming; 'An increasing amount of scientific information has been accumulated [supporting] the contention that contemporary global warming is human-induced due to greenhouse gas emissions rather than being part of a natural climate variability cycle' (Yumul et al., 2011). There is, however, controversy as to whether anthropogenic climate change is impacting the ENSO. According to Wisner et al., (2004), 'Considerable work over the past ten years on the El Niño Southern Oscillation suggest that these cycles of exceptionally wet and exceptionally dry weather, associated with periods of warming of surface water in the Pacific, may be increasing in frequency.' Similarly the Department of Environment and Natural Resources Climate Change Office (2010) is of the view 'that extreme events associated with the ENSO such as drought, floods, and storminess will be more intense and frequent as a result of the increase in temperature'. The Intergovernmental Panel on Climate Change (IPCC), however, remains unconvinced that climate change will intensify the ENSO; as Seneviratne et al. (2012) wrote, 'it is not possible at this time to confidently predict whether ENSO activity will be enhanced or damped due to anthropogenic climate change'.

Should there be intensified El Niño induced drought as a result of climate change there will undoubtedly be increased competition between mine operators and nearby communities for water; what the Department of Environment and Natural Resources Climate Change Office (2010) calls 'increasing threats to mine water supply security.' Also, with diminished water resources there will be a reduction in the archipelago's hydroelectric generating capacity. This is a concern on Mindanao where much electricity is hydroelectric and where, during the 2010 El Niño, there were frequent power outages. On 27 February 2010, for example, the Mindanao hydroelectric generating capacity fell by 78 percent necessitating rolling blackouts across the island and on 28 February 2010 the town of Mati, in Davao Oriental, was without power for 24 hours (Flores, 2010). The demands on Mindanao's electricity generating capacity are expected to grow in coming years as more mines are brought into production (Espejo, 2008). The Tampakan project, for example, is expected to require an additional 500 megawatts of generation capacity and by the year 2014 Mindanao could see an electricity generation shortfall of almost 1,500 megawatts (Lacorte, 2010).

The lack of consensus on the impact of anthropogenic climate change upon the ENSO demonstrate the importance of the precautionary principle, an important principle emerging from the United Nations Conference on Environment and Development, held in Rio de Janerio in 1992, which states, 'Where there are threats of serious or irreversible damage, lack of full scientific certainty shall not be used as a reason for postponing cost-effective measures to prevent environmental degradation' (United Nations, 1992). This principle is the 'premise that action should be taken to prevent harm to the environment and human health even if scientific evidence is inconclusive' (Emel \& Krueger, 2003). The government of the Philippines attended the Rio conference and, in a series of executive orders issued by President Fidel Ramos (Executive Order No. 15, 1992; Memorandum Order, No. 399, 1995; Executive Order No. 370, 1996) and President Gloria Macapagal-Arroyo (Executive Order No. 62, 2001) committed itself to its principles. An important implication of the precautionary principle is that relying upon mining as a development paradigm must consider the possibility that climate change will cause an increase in the frequency and severity of El Niño induced drought. For the government of the Philippines to aggressively promote mining as a method of development without taking into account an increase in the frequency and severity of El Niño events is to act in a manner inconsistent with its commitment to one of the most important principles of the Rio conference.

\subsection{Reducing the Risks through Environmental Impact Assessment?}

A policy tool that might be capable of reducing the risks posed by mining amid El Niño induced drought is environmental impact assessment (EIA), 'a systematic procedure for considering the possible effects of a proposed action on the environment prior to a decision being taken on whether approval should be given for the action to proceed and, if so, how it should proceed' (Wood \& Bailey, 1994). Environmental impact assessment is 'perhaps the most widely used tool of environmental management in the minerals sector' (Mining, Minerals, and Sustainable Development, 2002). In the Philippines all environmentally critical projects, such as large-scale mines, and all projects located in environmentally critical areas, such as areas vulnerable to natural calamities, cannot proceed without first submitting an environmental impact statement (EIS) to the government and receiving its authorization (Bravante \& Holden, 2009). Subjecting large-scale mining projects to an EIA may appear to be a vehicle for reducing the risks associated with allowing mining to occur amid El Niño induced 
drought but, in general, the EIA system for mining projects in the Philippines has been viewed as 'a tokenism, designed to make it appear as if mining projects are being evaluated with respect to their environmental impacts when really there is no serious intent to do so' (Bravante \& Holden, 2009).

One problem with the Philippine EIA system making it a weak vehicle for assessing the risks associated with locating mining projects in areas vulnerable to El Niño induced drought are its weak provisions for cumulative effects assessment (CEA); the process of considering not just the effects of a single project but also the effects of that project when taken in conjunction with other activities in its vicinity (Bravante \& Holden, 2009). With respect to mining, CEA is an important consideration; although a single mine creates its own set of environmental impacts, a 'regional concentration of mines poses problems of cumulative impact' (National Research Council, 1999). If a proposed mine is near other mines, or other human activities, there is a potential for effects that extend beyond what an isolated mine would cause. This is a serious concern when the cumulative effects of mining on groundwater resources are taken into account. As Ingelson et al. (2009) wrote:

A regional concentration of mines will cause cumulative impacts beyond those arising from a singe mine that can include water table draw down. When operations proceed beneath the water table, groundwater can flood the open pit and workings. Pumping to facilitate mineral extraction can result in groundwater withdrawal and depletion of an aquifer. Negative groundwater impacts are intensified by several mines in an area and reduced stream flow that can reduce the volume of water available for agriculture.

Given the concentrations of mines in northeastern Mindanao, an area at high risk of El Niño induced drought, and southeastern Mindanao, an area at very high risk of El Niño induced drought, CEA would appear to be an important aspect of the Philippine EIA system. However, in practice the EIA system consistently fails to consider cumulative effects (Bravante \& Holden, 2009). In the words of Ingelson et al. (2009), 'The EIA regime does not effectively address cumulative effects.' The EIS for the Tampakan Project, for example, made no mention of cumulative effects (AECOM Philippines Inc., 2011).

Another serious problem with the Philippine EIA system concerns its provisions for public participation. In the archipelago the EIA system has received substantial criticism for failing to avail meaningful opportunities for participation to members of the public (Bravante \& Holden, 2009). The public hearings in the process are discretionary, there is a very narrow definition of who may participate (it is confined only to those who may be directly and significantly affected by the project), and there is no required distribution of the EIS to the public as a way of soliciting public comment on it (Bravante \& Holden, 2009). With such limited facilities for public participation it is unlikely that the EIA system can become a participatory planning process.

\subsection{Best Practices in Environmental Management: Industry's Reply}

The mining industry is not oblivious to the hazards posed by the intersection of mining with El Niño induced drought; to it these hazards are serious but are more than capable of being overcome by their use of best practices in environmental management. As Xstrata (2010), the project proponent of the Tampakan Project wrote:

A detailed surface water model is being developed in current feasibility studies. Modeling and catchment analysis work is currently being reviewed to include risks associated with production demand, downstream baseline flows against various criteria including that of one in 1000 year drought events. This work will continue in 2009 as part of the feasibility and Environmental and Social Impact Assessment program. The water management plan will be developed in the context of both climate change and water stress and factor in the demands of the social population and environment.

In the EIS for the Tampakan Project the EIS preparer, AECOM Philippines Inc. (2011), downplayed concerns about the mine's water use by writing that 'the management of water resources is a critical aspect of the project.' 
Engineer Rene Cruz, a hydrology expert with AECOM Philippines Inc., attempted to assuage concerns about the Tampakan Project's impact on water resources by stating that competition between the Tampakan Project and other water users cannot occur as it is prohibited under Presidential Decree 1067 or the Water Code of the Philippines (Philippine Star, 2011). AECOM Philippines Inc. (2011) also wrote: 'A mine water management system has been formulated to provide a suitable water supply for the construction and operations of the project and to ensure that the project does not adversely impact the quality and availability of water for downstream water users.'

There are many who do not feel assured by such confident statements. 'While mining companies insist that their water use is highly efficient, communities and activists remain unconvinced and hydrologists tell us that the effects of removing large parts of rock in headwater areas can have non-linear, negative effects on water availability downstream' (Bebbington et al., 2008). Xstrata's assurance that it will use a 1000 year drought event as a baseline appears problematic. Any such predictions will be probabilistic models, at best, and certainly not robust statistical models designed with a high degree of reliability. Xstrata cannot obtain accurate precipitation data going back to the year 1008 as no records were kept going back that far on the island of Mindanao. Accurately predicting precipitation 1000 years into the future will be difficult to do given uncertainty surrounding the magnitude of climate change occurring over the next 1000 years (Seneviratne et al., 2012). The assurances of Engineer Rene Cruz that the Water Code of the Philippines will prevent competition between the Tampakan Project and other water users also appear problematic since the Water Code is routinely ignored by water users and does not apply to any wells shallower than 10 meters (Rodolfo \& Siringan, 2006).

The view expressed by the mining industry that its use of best practices in environmental management can overcome the hazards posed by the intersection of mining amid El Niño induced drought exemplify the concept of ecological modernization, a view which says that environmental problems 'can be resolved through appropriate technology and industrial retooling' (Emel \& Krueger, 2003). To Bebbington et al. (2008) the claims of the mining industry that its use of technology can minimize natural hazards 'constitute a discourse of ecological modernization par excellence.' The mining industry has become 'a vehicle for the more general argument that environmental risk can be managed, that society should therefore not be afraid in the face of such risk and that public risks are best managed privately' (Bebbington et al., 2008). The mining industry likes to depict itself as having undergone a profound transformation from the 'old mining', which damaged the environment, had dangerous workplaces and operated in complete disregard for the needs of adjacent communities, to the 'new mining,' which is socially and environmentally responsible and uses technology to ensure the management of environmental risk (Bebbington et al., 2008). To writers such as Emel and Krueger (2003) and Harvey (1996), ecological modernization is capitalism's response to environmental degradation. It shows that it is not necessary to forestall growth in order to protect the environment. Technology prevents environmental harm and corporate capitalism, by using such technology, can continue to be profitable.

\section{Results}

\subsection{Civil Society Opposition to Mining}

Concerns about mining's environmental effects have become widespread amongst members of Filipino civil society generating opposition to mining and providing a Philippine variant of the global phenomenon of what Bebbington et al. (2008) call the 'continuing and escalating protests around mining.' 'Civil society,' defined as the 'voluntary, rule-abiding, politically active sector of society, autonomous from the state' (Silliman \& Noble, 1998), is a potent force in Filipino society with the archipelago being renowned for its vibrant civil society including a dynamic collection of nongovernmental organizations (NGOs) involved in environmental advocacy on behalf of marginalized sectors of society such as the rural poor (Holden, 2005; Noble, 1998).

The opposition of civil society to mining in the Philippines has involved protests, the issuance of pastoral letters opposing mining by the hierarchy of the Roman Catholic Church, legal proceedings against mining, and the implementation of moratoriums banning large-scale mining by local government units (Holden, 2005, 2011). While not a full scale moratorium precluding all large-scale mining, the Province of South Cotabato passed a resolution banning open pit mining in June of 2010 (Lansang, 2011). Given the location of the Tampakan Project in South Cotabato, this was clearly directed to stop this mine as the project proponent has made it clear that it only intends to use open-pit methods (Xstrata, 2010). The national government has decried this ban (Note 1) on open pit mining declaring it to be inconsistent with the Mining Act of 1995 (Estabillo, 2011), and Xstrata (2011) has stated that 'we remain concerned about its potential effects and will continue to monitor the issue closely,' but South Cotabato has refused to rescind it. 


\subsection{The Alternative Mining Bill}

One of the most tangible manifestations of opposition to mining in the Philippines is the Alternative Mining Bill (AMB) pending in the Philippine Congress (Lansang, 2011). There are a number of provisions in the AMB designed to ameliorate the environmental and social effects of mining; in particular, some of them are specifically designed to address the intersection of mining with natural hazards. The bill contains a section prohibiting mining in areas prone to climatic disasters (such as El Niño induced drought) and this has been done to implement safeguards protecting vulnerable communities from mining's adverse environmental effects. It is highly unlikely that the AMB will pass and become law as 'the legislative area remains a very limited area for the passage of truly progressive legislation' (Taguiwalo, 2008). This is because 'the overwhelming majority of the legislators are adherents of neoliberalism, with a strong belief in the market' (Taguiwalo, 2008). Nevertheless, the AMB shows that not all members of Filipino society embrace the government's vision of a mining based development paradigm and the ability of the mining industry to overcome natural hazards by using best practices in environmental management.

\section{Discussion and Conclusions}

Disasters occur when a hazard impacts a vulnerable population. El Niño induced drought is a hazard impacting the Philippines and some El Niño events, such as the 1997-1998 El Niño, have occasioned substantial difficulties for the rural poor in areas affected by them. Large-scale mining projects, such as the Tampakan Project, occasion a substantial potential to aggravate the hazards posed by El Niño induced drought through their disruption of groundwater resources. During an El Niño induced drought the absence of precipitation will lead to reliance upon groundwater by the rural poor engaged in subsistence agriculture. If these groundwater resources are rendered unavailable, due to mining's interference with them, the situation will rapidly worsen and the rural poor will be thrust from subsistence into destitution. To Narcissa Baddilla, the Coordinator of the Save Manicani Movement on Manicani Island, water is one of the basics of sustaining life and if the supply of water is reduced their right to life is threatened (Baddilla, 2012).

The danger posed by mining in a place vulnerable to El Niño induced drought also demonstrates how economic globalization adversely interacts with a global atmospheric phenomenon. In the Philippines, as in many developing countries, the ascension of the neoliberal development paradigm has led to the promotion of mining as a method of generating economic development (Bebbington et al., 2008). Neoliberalism is an aggressive form of capitalism, proposing the advancement of human well-being 'by liberating individual entrepreneurial freedoms and skills within an institutional framework characterized by strong property rights, free markets, and free trade' (Harvey, 2005). In many ways, 'globalization' can be seen as the 'international face of neoliberalism' (Ward \& England, 2007). Indeed, globalization and neoliberalism have a powerful synergy between them; globalization is used to justify neoliberal policies wherein an interventionist state is viewed as a hindrance to economic development (Tyner, 2009). However, when the policy of promoting mining, a manifestation of economic globalization, is implemented in the Philippines it adversely interacts with the vulnerability of the archipelago to El Niño induced drought, a global atmospheric phenomenon. A similar example can also be found in Peru, a country that has also sought to promote mining (Renique, 2006). From 1999-2002, Manhattan Minerals, a Canadian mining company, attempted to develop an open pit gold mine in Tambogrande, Peru (Muradian et al., 2003). Peru is also a place where, during an El Niño event, there will be heavy rains with associated flooding (Van Aalst, 2006; Warner \& Ore, 2006). Just as the ATM in the Philippines oppose mining because an El Niño induced drought can adversely impact with mine pit dewatering, members of the Frente de Defensor de Tambogrande (Tambogrande Defense Front) in Tambogrande opposed the efforts of Manhattan Minerals to develop an open pit gold mine due to concern that the heavy rains associated with an El Niño event would cause mine workings to flood and contaminate the agricultural lands of Tambogrande (Maza, 2002; Moran, 2001). The opposition of the Frente de Defensor de Tambogrande ultimately led to Manhattan Minerals abandoning their attempts to develop the mine (Renique, 2006).

The difficulties in attempting to pursue a development program led by mining in the Philippines, with its vulnerability to El Niño induced drought, and with its vulnerable populations, indicate the absence of attention to natural hazards symptomatic of economic planning in the archipelago. The Philippines is a place where 'little or no consideration is given to natural hazards in economic planning' (Bankoff, 2003). A mining based development paradigm in the Philippines could well lead to events where mining-related water table drawdown aggravates an El Niño induced drought. Such 'disasters triggered by natural hazards,' wrote Schipper and Pelling (2006), 'are a consequence of development failure as much as failed development is the product of disaster'. 
In this context one may find the discussion provided by Bankoff and Hilhorst (2009) of 'development induced disasters' or 'development aggression' fruitful. Development aggression can be defined as, 'The process of displacing people from their land and homes to make way for development schemes that are being imposed from above without consent or public debate' (Nadeau, 2005). Development aggression may also be referred to as 'inappropriate development,' which is 'a globalizing economic and political process coming from outside that severely damages a community's culture, social organization and environment' (Nadeau, 2002). Should a mine be developed that disrupts the hydrology of a community the ground water of that community will be unavailable to its residents if there is an El Niño induced drought. In this event, they will clearly be made worse off, not better off; they will become the victims of development aggression. In Narcissa Baddilla's opinion, mining is development aggression because 'only the capitalists will become richer while they leave the island devastated' (Baddilla, 2012). After mining is completed on Manicani Island farming will be destroyed and the people on the island will be left poorer (Baddilla, 2012).

In contrast to development aggression, appropriate development refers to a process leading to the qualitative improvement of all members of society (Nadeau, 2002). Appropriate development may also be referred to as 'genuine development' and, to Ingelson et al. (2009) this is 'characterized by the efficient use of different types of natural capital including water.' This is where the Philippine EIA system, with its lack of attention to cumulative effects assessment, fails to ensure genuine development. 'The failure of the EIA system to protect renewable resources such as water and crops is another example of a deficiency in the EIA process that does not provide for genuine development' (Ingelson et al., 2009). Similarly, the weak provisions for public participation in the EIA system also fail to ensure genuine development. 'To facilitate genuine development in the Philippines, the system must provide for more public input and serious consideration of that input in the EIA process' (Ingelson et al., 2009). Genuine development is 'a processes in which people participate in making decisions and planning projects that affect their lives- where inhabitants of an area decide what kind of projects they want' (Broad, 1988). As Broad and Cavanagh (1993) wrote, 'The struggle for the environment, and for control of resources, requires a far more participatory notion of development'. In Narcissa Baddilla's words, 'mining will not bring "development," mining will not "develop" Manicani Island; let the people develop what they have instead of letting mining companies do it for them' (Baddilla, 2012).

It can be argued that strategies designed to achieve genuine development must have two aims: first, they must enable societies to be more resilient to hazards; second, they must ensure that development efforts do not increase vulnerability to hazards (O'Brien at al., 2006). In the Philippines, encouraging the development of large-scale mining projects does not enable the residents of the archipelago to become more resilient to hazards such as El Niño induced drought and they increase the vulnerability of Filipinos to such hazards. Such a policy is not development and it, quite likely, will lead to a disaster.

\section{References}

Abueme, V. C. (2012). President, Homonhon Environment Resources Organization, Personal Interview, Borongan, Eastern Samar, Philippines, 4 June.

AECOM Philippines Inc. (2011). Tampakan Copper-Gold Mine Project Environmental Impact Statement. Taguig City: AECOM Philippines Inc.

Alyansa Tigil Mina. (2010). Green Groups Call for Mining Moratorium to Mitigate El Niño Impacts. Retrieved June 17, 2010, from http://www.alyansatigilmina.net/content/story/february2010/green-groups-call-miningmoratorium-mitigate-el-ni\%C3\%B1o-impacts

Baddilla, N. (2012). Coordinator, Save Manicani Movement, Borongan, Personal Interview, Borongan, Eastern Samar, Philippines, 5 June.

Bankoff, G. (2003). Cultures of Disaster: Society and Natural Hazard in the Philippines. London: Routledge.

Bankoff, G., \& Hilhorst, D. (2009). The Politics of Risk in the Philippines: Comparing State and NGO $\begin{array}{llll}\text { Perceptions of Disaster Management. Disasters, 33(4), 686-704. } & \text {. }\end{array}$ http://dx.doi.org/10.1111/j.1467-7717.2009.01104.x

Bebbington, A., Hinojosa, I., Bebbington, D. H., Burneo, M. L., \& Warnaars, X. (2008). Contention and Ambiguity: Mining and the Possibilities of Development. Development and Change, 39(6), 887-914. http://dx.doi.org/10.1111/j.1467-7660.2008.00517.x

Bello, W., Docena, H., de Guzman, M., \& Malig, M. L. (2009). The Anti-Development State: The Political Economy of Permanent Crisis in the Philippines. Manila: Anvil Publishing. 
Bleiwas, D. I. (2012). Estimated Water Requirements for Gold Heap-Leach Operations: US Geological Survey Open-File Report 2012-1085. Reston, Virginia: United States Geological Survey.

Bravante, M. A., \& Holden, W. N. (2009). Going Through the Motions: the Environmental Impact Assessment of Nonferrous Metals Mining Projects in the Philippines. The Pacific Review, 22(4), 523-547. http://dx.doi.org/10.1080/09512740903128034

Bridge, G. (2007). Acts of Enclosure: Claim Staking and Land Conversion in Guyana's Gold Fields. In N. Heynen, J. Mccarthy, S. Prudham \& P. Robbins (Eds), Neoliberal Environments: False Promises and Unnatural Consequences (pp. 4-86). London: Routledge.

Broad, R. (1988). Unequal Alliance: The World Bank, the International Monetary Fund, and the Philippines. Berkley: University of California Press.

Broad, R. (1994). The Poor and the Environment: Friends or Foes? World Development, 22(6), 811-822. http://dx.doi.org/10.1016/0305-750X(94)90055-8

Broad, R., \& Cavanagh, J. (1993). Plundering Paradise: the Struggle for the Environment in the Philippines. Berkley: University of California Press.

Broad, R., \& Cavanagh, J. (2009). Development redefined: How the market met its match. London: Paradigm.

Burgonio, T. J. (2012). Mining EO a Virtual Warning to LGUs. Philippine Canadian Inquirer, 7(22), 16.

Dawe, D., Moya, P., \& Valencia, S. (2008). Institutional, Policy and Farmer Responses to Drought: El Niño Events and Rice in the Philippines. Disasters, 33(2), 291-307. http://dx.doi.org/10.1111/j.1467-7717.2008.01075.x

Department of Environment and Natural Resources Climate Change Office. (2010). The Philippine Strategy on Climate Change Adaptation. Quezon City: Department of Environment and Natural Resources Climate Change Office.

Emel, J., \& Krueger, R. (2003). Spoken but not Heard: the Promise of the Precautionary Principle for Natural Resource Development. Local Environment, 8(1), 9-25. http://dx.doi.org/10.1080/135498303200041304

Espejo, E. G. (2008). Power Crisis Looms in Mindanao. MindaNews. Retrieved January 18, 2008, from $\mathrm{http}: / /$ www.mindanews.com/index.php?option=com_content\&task=view\&id=3664\&Itemid $=50$

Estabillo, A. V. (2007). Group Warns of South Cotabato's Vanishing Water Resources. MindaNews. Retrieved June 19, 2010, from http://www.mindanews.com/index.php?option=com_content\&task=view\&id=3488\& Itemid $=106$

Estabillo, A. V. (2011). PNoy Wants South Cot's Open-Pit Mine Ban Controversy Resolved. MindaNews. Retrieved November 18, 2011, from http://mindanews.com/main/2011/04/17/pnoy-wants-south-cot $\% \mathrm{E} 2 \% 8$ 0\%99s-open-pit-mine-ban-controversy-resolved

Flores, A. (2010). 'Power, Food Crises Feared' Manila Standard Today. Retrieved June 18, 2010, from http://www.manilastandardtoday.com/insideNation.htm?f=2010/march $/ 1 /$ nation1. isx\&d=2010/march $/ 1$

Forestry Management Bureau, Department of the Environment and Natural Resources. (2010). Forest Cover by Region. Retrieved June 16, 2010, from http://forestry.denr.gov.ph/landusereg.htm

Fraser Institute. (2008). Fraser Institute Annual Survey of Mining Companies 2007/2008. Vancouver: Fraser Institute.

Harvey, D. (1996). Justice, Nature, and the Geography of Difference. Oxford: Blackwell.

Harvey, D. (2005). A Brief History of Neoliberalism. Oxford: Oxford University Press.

Heaney, L. R., \& Regalado, J. C. (1998). Vanishing Treasures of the Philippine Rain Forest. Chicago: The Field Museum.

Holden, W. N. (2005). Civil Society Opposition to Nonferrous Metals Mining in the Philippines. Voluntas, 16(3), 223-249. http://dx.doi.org/10.1007/s11266-005-7723-1

Holden, W. N. (2011). A Lack of Faith in Technology? Civil Society Opposition to Large-Scale Mining in the Philippines. The International Journal of Science in Society, 2(2), 274-299.

Holden, W. N., \& Jacobson, R. D. (2012). Mining and Natural Hazard Vulnerability in the Philippines: Digging to Development or Digging to Disaster? London: Anthem Press.

IBON. (2006). The State of the Philippine Environment. Quezon City: IBON Foundation. 
Ingelson, A., Holden, W. N., \& Bravante, M. A. (2009). Philippine Environmental Impact Assessment, Mining, and Genuine Development. Law, Environment, and Development Journal, 5(1), 1-15.

Isip, E. (2005). Director, Southeast Mindanao Protected Areas and Wildlife Bureau, Department of Environment and Natural Resources, Personal Interview, Davao City, Philippines, 3 June.

Katz. R. W. (2002). Sir Gilbert Walker and a Connection between El Niño and Statistics. Statistical Science, 17(1), 97-112. http://dx.doi.org/10.1214/ss/1023799000

Kuipers, J. R. (2005). The Environmental Legacy of Mining in New Mexico. In L. G. Price, D. Bland, V. T. McLemore \& J. M. Barker (Eds), Mining in New Mexico: the Environment, Water, Economics, and Sustainable Development (pp. 46-49). Socorro, New Mexico: New Mexico Bureau of Geology and Mineral Resources.

Lacorte, G. (2010). Mining Industry to Raise Power Demand in Mindanao by 1,000MW. MindaNews. Retrieved November 18, 2011, from http://mindanews.com/main/2010/11/08/mining-industry-to-raise-power-demand -in-mindanao-by-1000mw

Lansang, L. G. F. (2011). NGOs, Coalition Building and the Campaign for a Minerals Management Policy in the Philippines. Philippine Political Science Journal, 32(55), 127-166. http://dx.doi.org/10.1080/01154451.2011.9723534

Manila Observatory. (2011). Mapping Philippine Vulnerability to Environmental Disasters. Retrieved November 18, 2011, from http://www.observatory.ph/vm/maps.html

Maza, C. C. (2002). Member, Frente de Defensor de Tambogrande, Personal Interview, Tambogrande, Peru, 22 August.

Mines and Geosciences Bureau. (2006). Priority Mineral Development Projects of the Philippines. Department of Environment and Natural Resources. Quezon City: Department of Environment and Natural Resources, Mines and Geosciences Bureau.

Mines and Geosciences Bureau. (2007a). Philippine Mining Development Projects Profile. Quezon City: Department of Environment and Natural Resources, Mines and Geosciences Bureau.

Mines and Geosciences Bureau. (2007b). Mineral Exploration Projects in the Philippines. Quezon City: Department of Environment and Natural Resources, Mines and Geosciences Bureau.

Mines and Geosciences Bureau. (2007c). Priority Mineral Development Projects of the Philippines. Quezon City: Department of Environment and Natural Resources, Mines and Geosciences Bureau.

Mining, Minerals, and Sustainable Development. (2002). Breaking New Ground. London: Earthscan Publications.

Moody, R. (2007). Rocks and Hard Places: The Globalization of Mining. London: Zed Books.

Moran, R. (2001). An Alternative Look at a Proposed Mine In Tambogrande Peru. Washington: Oxfam America.

Muradian, R. J., \& Martinez-Alier, H. C. (2003). International Capital versus Local Population: The Environmental Conflict of the Tambogrande Mining Project, Peru. Society and Natural Resources, 16(8), 775-792. http://dx.doi.org/10.1080/08941920309166

Myers, N. (1988). Environmental Degradation and Some Economic Consequences in the Philippines. Environmental Conservation, 15(3), 303-311. http://dx.doi.org/10.1017/S0376892900029337

Nadeau, K. M. (1992). Capitalist Southeast Asian Peasants: Some Thoughts on an Old Debate. Philippine Sociological Review, 40(1), 57-75.

Nadeau, K. M. (2002). Liberation Theology in the Philippines: Faith in a Revolution. Westport, Connecticut: Praeger.

Nadeau, K. M. (2005). Christians against Globalization in the Philippines. Urban Anthropology, 34(4), 317-339.

National Research Council. (1999). Hardrock Mining on Federal Lands. Washington: National Academy Press.

Neri, R. L. (2005). Importance of the Mining Sector to the Philippine Economy. Manila: National Economic Development Authority.

Noble, L. G. (1998). Environmental Activism. In G. S. Silliman \& L. G. Noble (Eds), NGOs, Civil Society, and the Philippine State (pp.193-222). Honolulu: University of Hawaii Press. 
O’Brien, G., O’Keefe, P., Rose, J., \& Wisner, B. (2006). Climate Change and Disaster Management. Disasters, 30(1), 64-80. http://dx.doi.org/10.1111/j.1467-9523.2006.00307.x

Peet, R., \& Hartwick, E. (2009). Theories of Development: Contentions, Arguments, Alternatives. New York: Guildford Press.

Philander, S. G. H. (2004). Our Affair with El Niño. How we Transformed an Enchanting Peruvian Current into a Global Climate Hazard. Princeton: Princeton University Press.

Philippine Star. (2011). Malacañang Expresses Full Support For Mining Industry. Retrieved May 15, 2011, from http://www.philstar.com/Article.aspx?articleId=642115\&publicationSubCategoryId=67

Renique, G. (2006). Strategic Challenges for Latin America's Anti-Neoliberal Insurgency. In V. Prashad \& T. Ballve (Eds), Dispatches from Latin America: On the Frontlines against Neoliberalism (pp. 35-46). Cambridge, Massachusetts: South End Press.

Rodolfo, K. S., \& Siringan, F. S. (2006). Global Sea-Level Rise is Recognized, but Flooding from Anthropogenic Land Subsidence is Ignored Around Northern Manila Bay, Philippines. Disasters, 30(1), 118-139. http://dx.doi.org/10.1111/j.1467-9523.2006.00310.x

Roque, C. R., \& Garcia, M. I. (1993). The Ecology of Rebellion: Economic Inequality, Environmental Degradation and Civil Strife in the Philippines. Solidarity, 139(140), 88-120.

Schipper, L., \& Pelling, M. (2006). Disaster Risk, Climate Change and International Development: Scope for, and Challenges to, Integration. Disasters, 30(1), 19-38. http://dx.doi.org/10.1111/j.1467-9523.2006.00304.x

Seasonal Climate Forecast Project Updates. (2006). Corn Farming Communities are Among the Most Impoverished. Seasonal Climate Forecast Project Updates, 2(1-2), 7.

Seneviratne, S. I. et al. (2012). Changes in Climate Extremes and their Impacts on the Natural Physical Environment. In C. B. Field et al. (Eds), Managing the Risks of Extreme Events and Disasters to Advance Climate Change Adaptation: A Special Report of the Intergovernmental Panel on Climate Change (pp. 109-230). Cambridge: Cambridge University Press. http://dx.doi.org/10.1017/CBO9781139177245.006

Shomaker, J. W. (2005). Will there be Water to Support Mining's Future in New Mexico? In L. G. Price, D. Bland, V. T. McLemore \& J. M. Barker (Eds), Mining in New Mexico: the Environment, Water, Economics, and Sustainable Development (pp. 128-130). Socorro, New Mexico: New Mexico Bureau of Geology and Mineral Resources.

Silliman, G. S., \& Noble, L. G. (1998). Introduction. In G. S. Silliman \& L. G. Noble (Eds), NGOs, Civil Society, and the Philippine State (pp. 3-25). Honolulu: University of Hawaii Press.

Strongman, J. (1994). Strategies to Attract New Investment for African Mining. Washington: World Bank.

Taguiwalo, J. M. (2008). The UP-wide Democratization Movement and the Struggle for a Democratic University of the People. In B. Lumbera, J. Taguiwalo, R. Tolentino, R. Guillermo \& A. Alamon (Eds), Serve the People: Ang Kasaysayan ng Radikal na Kilusan sa Unibersidad ng Pilipinas (pp. 325-330). Quezon City: IBON Books.

Tyner, J. A. (2009). The Philippines: Mobilities, Identities, Globalization. London: Routledge.

United Nations. (1992). Report of the United Nations Conference on Environment and Development. UNCED Report A/CONF.121/5/Rev.1 13 June 1992. Retrieved July 18, 2012, from http://www.un.org/documents/ga/conf151/aconf15126-1annex1.htm

United States Bureau of Mines. (1970). Minerals Yearbook, Reston, Virginia: U.S. Bureau of Mines.

Van Aalst, M. K. (2006). The Impacts of Climate Change on the Risk of Natural Disasters. Disasters. 30(1), 5-18. http://dx.doi.org/10.1111/j.1467-9523.2006.00303.x

Ward, K., \& England, K. (2007). Introduction: Reading Neoliberalization. In K. Ward \& K. England (Eds), Neoliberalization: States, Networks, Peoples (pp. 1-22). Blackwell, Oxford.

Warner, J., \& Ore, M. T. (2006). El Niño Platforms: Participatory Disaster Response in Peru. Disasters, 30(1): 102-117. http://dx.doi.org/10.1111/j.1467-9523.2006.00309.x

Wisner, B., Blaikie, P., Cannon, T., \& Davis, I. (2004). At Risk: Natural Hazards, People's Vulnerability and Disasters (2nd ed.). London: Routledge. 
Wood, C., \& Bailey, J. (1994). Predominance and Independence in Environmental Impact Assessment: The Western Australian Model. Environmental Impact Assessment Review, 14(1), 37-59. http://dx.doi.org/10.1016/0195-9255(94)90041-8

World Bank. (1992). Strategy for African Mining. World Bank Technical Paper Number 181 Africa Technical Department Series Mining Unit, Industry and Energy Division. Washington: World Bank.

Xstrata. (2008). Tampakan Project: Sustainability Report 2007. Zug, Switzerland: Xstrata Copper.

Xstrata. (2010). Tampakan Project: Sustainability Report 2009. Zug, Switzerland: Xstrata Copper.

Xstrata. (2011). Tampakan Project: Sustainability Report 2010. Zug, Switzerland: Xstrata Copper.

Yumul, G. P., Cruz, N. A., Servando, N. T., \& Dimalanta, C. B. (2001). Extreme Weather Events and Related Disasters in the Philippines, 2004-08: A Sign of What Climate Change Will Mean? Disasters, 35(2), 362-382. http://dx.doi.org/10.1111/j.1467-7717.2010.01216.x

\section{Note}

Note 1. Largely in response to South Cotabato's ban on open pit mining President Benigno Aquino issued Executive Order No. 79 on 6 July 2012 ordering, in Section 12, all local governments to 'confine themselves only to the imposition of reasonable limitations on mining activities conducted within their respective territorial jurisdictions that are consistent with national laws and regulations.' This Executive Order is controversial as it is unclear whether a presidential executive order can invalidate a resolution passed by a provincial government (Burgonio, 2012). 